\title{
A Comparative Study of the Ileum in Rat (Rattus norvegicus), Bat (Eidolon helvum) and Pangolin (Manis tricuspis) as Investigated Using Histological Method
}

\author{
Estudio Comparativo del Íleon en Rata (Rattus norvegicus), Murciélago (Eidolon helvum) \\ y Pangolín (Manis tricuspis) Utilizando como Investigación el Método Histológico \\ ${ }^{*, * *}$ Ofusori, D. A; *** Caxton-Martins, E. A.; ${ }^{* * * *}$ Komolafe, O. O.; ${ }^{*}$ Oluyemi, K. A.; ${ }^{* *}$ Adeeyo, O. A.; \\ "**Ajayi, S. A.; "** Oluwayinka, P. O.; ${ }^{* * *}$ Adelakun, E. A.; ${ }^{* *}$ Keji, S. T. \& *Adesanya, O. A.
}

OFUSORI, D. A; CAXTON-MARTINS, E. A.; KOMOLAFE, O. O.; OLUYEMI, K. A.; ADEEYO, O. A.; AJAYI, S. A.; OLUWAYINKA, P. O.; ADELAKUN, E. A.; KEJI, S. T. \& ADESANYA, O. A. A comparative study of the ileum in rat (Rattus norvegicus), bat (Eidolon helvum) and pangolin (Manis tricuspis) as investigated using histological method. Int. J. Morphol., 26(1):137$141,2008$.

SUMMARY: The histological and morphometric differences in some parts of the gastrointestinal tracts of rat, bat and pangolin have been well established. This investigation aims at comparatively elucidating any adaptational changes the ileum of the three mammals must have adopted to meet its dietary requirements and also cope with their morphological differences. The investigation was carried out using ten rats, ten bats and ten pangolins of both sexes. The animals were slightly anaesthetized under chloroform inhalation. The intestines were harvested and the ileum excised and fixed in $10 \%$ formol saline. The tissues were processed for light microscopic study. The following stains were employed: Haematoxylin and eosin (H \& E), Van Gieson and Verhoeff's haematoxylin elastic tissue stain. Stained slides were also analysed morphometrically. The results revealed microstructural modifications which characterized the mucosa as well as the pattern of distribution of the conjuntive tissue fibers in the ileum of the three mammals. These modifications are means of successfully coping with their respective diets and morphological differences.

KEY WORDS: Pangolin; Bat; Rat; Ileum; Microanatomy; Conjuntive tissue.

\section{INTRODUCTION}

Pangolin, bat and rat are mammals (Hildebrand \& Goslow, 2001). While bat is an arboreal (Ogunbiyi \& Okon, 1976), pangolin and rat are terrestrial (Hildebrand \& Goslow). The three mammals were chosen out of the numerous mammals because of the accessibility and previous comparative works done which centered on their diet, nutrition, morphology. Rouk \& Glass (1970) worked on the gastric morphology of Desmodus rotundus in relation to diet. Hildebrand \& Goslow showed length and approximate diameter of small intestine, large intestine and caecum for several species. Gidenne (1992) investigated the effect of fibre level, particle size and adaptation period on digestibility and range of passage as measure at the ileum.

No precise work has been done to relate all these differences with the microanatomical adaptations which the ileum (an important part of the gastrointestinal tract) has adopted. The soft internal parts of invertebrate along with their flesh do contain protein and fat which provide the nutrient needed by Pangolin and other ant-eaters (Redford $\&$ Dorea, 1984). The sand and ditrus adsorbed together with the termite has been reported to add bulk to the digestive load of insectivores and thus, reduced the caloric proportion of their digestive content (Redford, 1983).

Studies have been done on straw-colored fruit-eating bats by Okon (1974) and Cork (1996). The tongue which has sharp and backward pointing rasps or papillae on the upper surface is moved forwards and backwards and sometimes sideways, rasping away the fruits rich in fibre

\footnotetext{
* Department of Anatomy, School of Basic Medical Sciences, Igbinedion University, Okada, P.M.B 0006, Benin City, Edo State. Nigeria.

** Department of Anatomy and Cell Biology, Faculty of Basic Medical Sciences, Obafemi Awolowo University, Ile-Ife, Nigeria.

*** Department of Chemistry, Faculty of Science, University of Lagos,Akoka, Nigeria.

**** Department of Zoology, Faculty of Science, Obafemi Awolowo University, Ile-Ife, Nigeria.
} 
OFUSORI, D. A; CAXTON-MARTINS, E. A.; KOMOLAFE, O. O.; OLUYEMI, K. A.; ADEEYO, O. A.; AJAYI, S. A.; OLUWAYINKA, P. O.; ADELAKUN, E. A.; KEJI, S. T. \& ADESANYA, O. A. A comparative study of the ileum in rat (Rattus norvegicus), bat (Eidolon helvum) and pangolin (Manis tricuspis) as investigated using histological method. Int. J. Morphol., 26(1):137-141, 2008.

contents in a kind of grating action. Unlike the bat, the permanently growing incisors; two on top and two below are used for the manipulation of food (Plant and animal materials) in rats. Caroline et al. (2003) gave the account of diet of six months old Rattus norvegicus to include $4 \%$ fibres.

This they say increase as Rattus norvergicus gets to adulthood. Other general life style and food preference of the three mammals have been studied extensively by Griffiths $e t$ al. (1990), Cohan (1984), Anderson \& Akanji (1993), Bellier \& Gidenne (1996), Cork, Dado \& Allen (2000), Gidenne, Kingdon (1974), Caroline et al. and Thomas (1991).

The ileum is the final section of the small intestine. It is about 2-4m long in man, follows the duodenum and jejunum, and is separated from the ceacum by the ileoceacal valve (Coico et al., 2003).

Its function is to absorb vitamin B12 and bile salts. (Saladin, 2004). The wall itself is made up of folds, each of which has many tiny finger-like projections known as villi, on its surface. Between the bases the villi are formed into crypt, called crypt of Liberkühn. In turn, the epithelial cells, which line these villi, possess even larger numbers of microvilli. Therefore the ileum has an extremely large surface area both for the adsorption (attachment) of enzyme molecules and for the absorption of products of digestion (Heath et al., 1999). The cells that line the ileum contain the protease and carbohydrase enzymes responsible for the final stages of protein and carbohydrate digestion. These enzymes are present in the cytoplasm of the epithelial cells (Hildebrand \& Goslow). The villi contain large numbers of capillaries, which take the amino acids and glucose produced by digestion to the hepatic portal vein and the liver (Wilson, 1967). Lacteals are small lymph vessels, and are present in villi. They absorb fatty acid and glycerol, the products of fatty digestion. Layers of circular and longitudinal smooth muscle enable the digested food to be pushed along the ileum by waves of muscle contraction called peristalsis (Heath et al.).

In this study, we comparatively elucidate the microstructural organization, types and prevalent conjuntive tissue fibres adopted by the Ileum of the three mammals to successfully manipulate their different diets and cope with the morphological differences.

\section{MATERIAL AND METHOD}

Care of the animals. Ten rats, ten bats and ten pangolins of equal sexes were procured. The rats were obtained and maintained in the Animal Holdings of the Department of Anatomy and Cell Biology, Obafemi Awolowo University,
Ile-Ife, Nigeria. They were fed with rat pellets and given water ad libitum. The bats were curled from their roosting colony on the Obafemi Awolowo University campus following ethical clearance and maintained in the animal holdings of the same Department. They were fed with ripe bananas and water. The pangolins were procured 24 hours prior to sacrifice. The animals were carefully assessed, screened and confirmed to be presumably free of any pathological conditions. Handling and care of the animals conform to the animal right committee of the Obafemi Awolowo University, Ile-Ife, Nigeria.

Excision of the ileum. The ileums were excised from the animals after a midline abdominal incision following slight anesthesia using chloroform. The collected tissues were perfused with physiological saline and blotted dry on a filter paper.

Histological procedures. The tissues were fixed in $10 \%$ formol saline for 48 hours and processed routinely for paraffin embedding. Serial sections were obtained at $5 \mu \mathrm{m}$ thickness from a rotary microtome and subjected to the following staining procedures: Haematoxylin and Eosin (H\&E), Van Gieson, and Verhoeff's Haematoxylin elastic tissue stain.

Morphometric Analysis. The stained sections were subjected to morphometric analysis recommended by World Health Organization W.H.O. (1991) which included: dividing the eye piece occulometer into two 100 small divisions, the stage micrometer scale was made up to $1 \mathrm{~mm}$ divided into $0.1 \mathrm{~mm}$ divisions and each $0.1 \mathrm{~mm}$ was divided into $0.01 \mathrm{~mm}$, the eye piece scale (occulometer) was inserted into the eye piece of the microscope by removing the superior lens thus placing the scale on the field stop, the stage micrometer was also placed on the stage of the microscope, the stage scale was focused by the low power objective lens (x4), the stage and the eye piece scales were adjusted until there was a parallel point between the two scales, the number of the eye piece divisions and its corresponding stage measurements was noted; (if 70 occulometer divisions equal to $14 \mu \mathrm{m}$, all the objective lens were thus calibrated). Calibration was needed for each microscope use. The occulometer fixed into the Olympus Microscope was then focused through stained sections of the tissue to allow for the measurement of the lengths of the villi and thicknesses of muscularis externa.

\section{RESULTS}

The histological investigation revealed the presence of simple columnar epithelium in the ileum of the three mammals. They were observed to conform to the basic 
OFUSORI, D. A; CAXTON-MARTINS, E. A.; KOMOLAFE, O. O.; OLUYEMI, K. A.; ADEEYO, O. A.; AJAYI, S. A.; OLUWAYINKA, P. O.; ADELAKUN, E. A.; KEJI, S. T. \& ADESANYA, O. A. A comparative study of the ileum in rat (Rattus norvegicus), bat (Eidolon helvum) and pangolin (Manis tricuspis) as investigated using histological method. Int. J. Morphol, 26(1):137-141, 2008

structural organization which includes the presence of mucosa, submucosa, and muscularis externa. The mucosa of the pangolin were noticed to be characterized by horizontal folds called plicae circulares (Fig 1,2 and 3) in contrast with a normal finger-like projection (villi) found projecting in to the lumen in rats and bats (Fig 1, 2 and 3). The plicae circulares were however studded with villi thus increasing the surface area. Further examination revealed that the muscularis externa is thicker in pangolin compared with rat and bat (Table I). Lymphocytes also predominates the mucosa layer in the ileum of the three mammals. Collagen fibers were observed to be moderately stained distributed in the submucosa of the rat and pangolin-pinkish/red colouration (Fig 2), just as the elastic fibers were observed to be moderately stained (black colouration) in the muscularis externa of the three mammals (Fig 3).
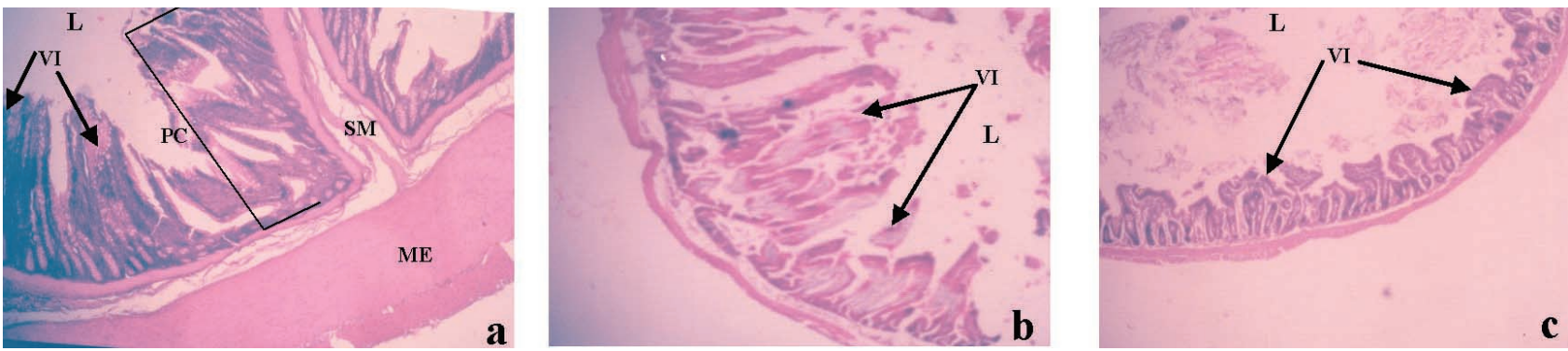

Fig. 1. Photomicrograph of the ileum of (a) pangolin. Note the lumen (L) and the presence of plicae circulares (PC) with its submucosa (SM), which is absent in $\mathrm{b}$ and $\mathrm{c}$. The absorptive surface area is further augmented by intraluminal mucosa projections, villi (VI). Muscularis externa (ME). (b) Bat. Note the similarity in the villi (VI) in b and c as compared with a. Also, note the lumen (L). (c) Rat. Note the lumen (L) and villi (VI) H \& E (x 40).
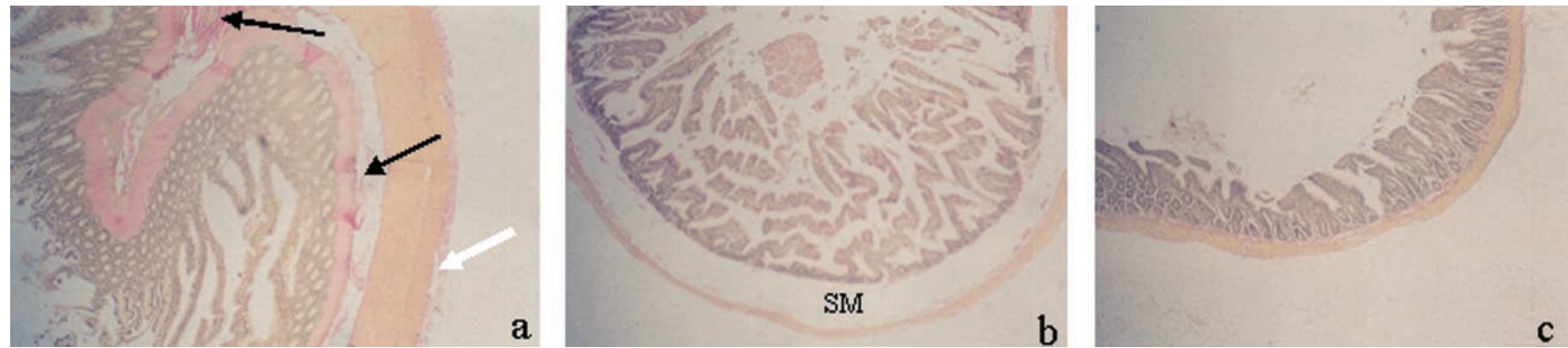

Fig. 2. Photomicrograph of the Ileum of (a) pangolin. Note some few strands of collagen fibres in the serosa (white arrow) and submucosa (black arrow) (b) Bat. Note the complete absence of collagen fibres in the submucosa (SM) as compared with a \& c. (c) Rat. Van Gieson (x40).
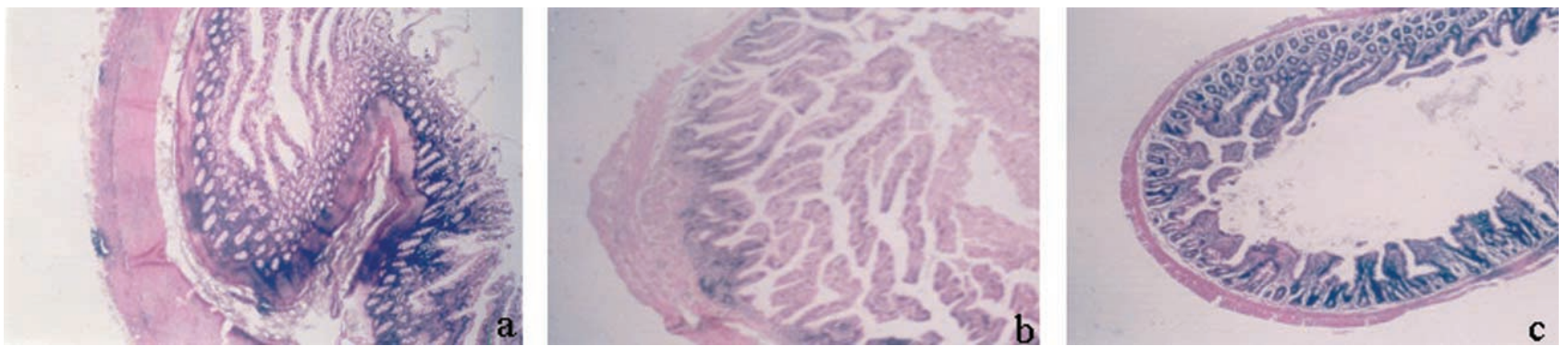

Fig. 3. Photomicrograph of the ileum of (a) Pangolin. (b) Bat. (c) Rat. Verhoeff's (x 40). Note the similar distribution of elastic fibres in the mucosa (black deposits) in a \& c as compared with a lesser staining intensity in $b$.

Table I. A comparative study of the structure of ileum between bat, rat and pangolin (Mean \pm S.E.)

$\begin{array}{lccc} & \text { BAT } & \text { RAT } & \text { PANGOLIN } \\ \text { Length of villi }(\boldsymbol{\mu m}) & 849 \pm 43.61 & 290 \pm 32.52 & 537 \pm 26.14 \\ \text { Thickness of muscularis externa } & 110 \pm 11.07 & 69 \pm 13.35 & 468 \pm 41.09 \\ \text { Plicae Circulares } & \text { Absent } & \text { Absent } & \text { Present }\end{array}$


OFUSORI, D. A; CAXTON-MARTINS, E. A.; KOMOLAFE, O. O.; OLUYEMI, K. A.; ADEEYO, O. A.; AJAYI, S. A.; OLUWAYINKA, P. O.; ADELAKUN, E. A.; KEJI, S. T. \& ADESANYA, O. A. A comparative study of the ileum in rat (Rattus norvegicus), bat (Eidolon helvum) and pangolin (Manis tricuspis) as investigated using histological method. Int. J. Morphol., 26(1):137-141, 2008.

\section{DISCUSSION}

The similar micro-structural arrangement of the coat in the ileum of the three mammals is a peculiar characteristic of a typical tubular organ, which is in agreement with the work of Heath et al. Simple columnar epithelium observed also conforms to the normal acceptable feature of the gastrointestinal tract (Hildebrand \& Goslow; Heath et al.; Wilson and Coico et al.). The histoarchitectural modification of the mucosa of the pangolin's ileum into plicae circulares (Fig.1) in contrast to bat and rat may be an adaptation needed to enhance the surface area and attenuate the forward flow of intraluminal contents, thus, increasing the time of contact with absorptive surfaces. This adaptation may probably be a strategy to make up for the short intestine and absent colon. These findings agreed with the works of Rubin (1971) and Wilson. Further, the similarities in the histoarchitectural configuration of the villi in rat and bat (Fig.1) are believed to be indicative of similar way of coping with their high fibre diets. The work of Okon revealed that fruits rich in fibres are normally consumed by Eidolon helvum, while the seed and some hard fibres are often rejected. A similar work by Caroline et al., also revealed that large percentages of fibres are contained in the daily intake of Rattus norvegicus. The increase in length of the villi in bat as compared with rat and Pangolin (Table I) underlines its functional implication. It appears to also play a cilliary role, which helps to complement the peristaltic movement of chyle against gravity when the animals are in their normal (up-side-down) posture. The presence of lymphocytes in the ileum of the three mammals may be a means of coping with microorganisms and virus-infected enterocytes in support of investigation of Heath et al., on lymphocytes in human gastro-intestinal tract. Other micro-structural components present, are believed to be adaptations needed to cope with the stress generated by the peristaltic movement that characterize the intestine as evidenced in the moderate staining intensity of the collagen fibers in rat and pangolin (Fig. 2), which is a reflection of the moderate tensile strength required to accommodate the peristaltic stress. Absence of collagen fibers in the submucosa of bat further affirms the complimentary role of the villi in fecal movement, which has reduced the tensile strength that would have allowed for the presence of collagen fibers. The moderately stained elastic fibres in the muscularis externa of the ileum in the three mammals (Fig. 3) also underline their functional implications. This reflects the moderate stretching and recoiling mechanism needed to propel the chyle. It is therefore worthy of conclusion that though the three animals belong to the same class-Mammalia, there is need for adaptational means of coping with their respective dietary and morphological differences as evidenced in the microanatomy of the ileum of the three mammals. There is still a wide scope for more extensive study adopting histochemical means to determine some enzymes of carbohydrate metabolism. The result of such investigation apart from unveiling the conventional pathways adopted by the ileum of the three mammals to meet its energy demand, could be a useful tool to study some other areas of the biology of this three mammals.

\section{ACKNOWLEDGEMENT}

We are thankful to Prof. C.O Adewunmi of the Faculty of Pharmacy Obafemi Awolowo University, Nigeria, for his assistance during the photomicrography. Our regards also goes to Kola Oyewole, Oluwaseun Timothy and Inioluwa Gbela for their technical assistance.

OFUSORI, D. A; CAXTON-MARTINS, E. A.; KOMOLAFE, O. O.; OLUYEMI, K. A.; ADEEYO, O. A.; AJAYI, S. A.; OLUWAYINKA, P. O.; ADELAKUN, E. A.; KEJI, S. T. \& ADESANYA, O. A. Estudio comparativo del íleon en rata (Rattus norvegicus), murciélago (Eidolon helvum) y pangolin (Manis tricuspis) utilizando como investigación el método histológico. Int. J. Morphol., 26(1):137141, 2008.

Las diferencias histológicas y morfométricas en algunas partes del tubo digestivo de ratas, murciélagos y pangolines han sido bien establecidos. Esta investigación tiene por objeto aclarar comparativamente cualquier cambio de adaptación del íleon de los tres mamíferos que hayan adoptado para satisfacer sus necesidades dietéticas y también hacer frente a sus diferencias morfológicas. La investigación se llevó a cabo usando 10 ratas, 10 murciélagos y 10 pangolines, de ambos sexos. Los animales fueron ligeramente anestesiados bajo inhalación de cloroformo. Los intestinos fueron expuestos, el íleon extirpado y fijado en formol salino al $10 \%$. Los tejidos fueron procesados para su estudio por microscopía de luz. Los siguientes tinciones fueron empleadas: Hematoxilina y eosina (H \& E), Van Gieson y tinción de hematoxilina para tejidos elásticos de Verhoeff. Los cortes teñidos también se analizaron morfométricamente. Los resultados revelaron modificaciones microestructurales características de la mucosa, así como el patrón de distribución de las fibras de tejido conjuntivo en el íleon de los tres mamíferos. Estas modificaciones son el medio para entender sus diferencias en la dieta y morfología respectivamente.

PALABRAS CLAVE: Pangolin; Murciélago; Rata; Íleon; Microanatomía, Tejido Conjuntivo. 
OFUSORI, D. A; CAXTON-MARTINS, E. A.; KOMOLAFE, O. O.; OLUYEMI, K. A.; ADEEYO, O. A.; AJAYI, S. A.; OLUWAYINKA, P. O.; ADELAKUN, E. A.; KEJI, S. T. \& ADESANYA, O. A. A comparative study of the ileum in rat (Rattus norvegicus), bat (Eidolon helvum) and pangolin (Manis tricuspis) as investigated using histological method. Int. J. Morphol., 26(1):137-141, 2008.

\section{REFERENCES}

Anderson, J. W. \& Akanji, A. O. Treatment of diabetes with high fiber diets, Hand book of dietary fiber in human nutrition. Boca Raton, CRC press, 1993.

Bellier, R. T. \& Gidenne, T. Consequences of reduced fiber in take on digestion, rate of passage and caecal microbial activity in young rabbit. British. J. Nut., 75:353-63, 1996.

Caroline, J.; Gross, M. S. \& Dian-Marie, S. Fiber digestion in mammals. Pak. J. Biol. Sci., 6(17):1564-73, 2003.

Cohan, F. M. Can uniform selection retard random genetic divergence between isolated conspecific populations. Evolution, 38:495-504, 1984.

Coico, R. F.; Sunshine, G. \& Benjamini, E. Immunology: A Short Course. $5^{\text {th }}$ Ed. Hoboken, John Wiley \& Sons, 2003.

Cork, S. J. Optimal digestive strategies for arboreal herbivores mammals in contrasting forest types. Australian J. Ecol., 21:10-20, 1996.

Dado, R. G. \& Allen, M. S. Intake limitations, feeding behaviour, and rumen function of cows challenged with rumen fill from dietary fiber of inert bulk. J. Dietary Sci., 71:118-33, 2000.

Gidenne, T. Effect of fiber level, particles size, and adaptation period on digestibility and range of passage as measured at the ileum and in the feces in the adult rabbit. British $J$. Nut., 67:133-46, 1992.

Griffiths, M.; Greenslade, P. J. M.; Miller, L. \& Kerle, J. A. The diet of the Spiny-Anteater (Tachyglossus aculeatus acanthion) in tropical habitats in the Northern Territory. The Beagle, Records of the Northern Territory Museum of Arts and Science. The Beagle, 7(1):79-90, 1990.

Heath, J. W.; Young, B. \& Burkitt, H. G. Gastrointestinal tract. In: Wheater's functional histology. $3^{\text {rd }} \mathrm{Ed}$. New York, Churchill Livingstone,1999. pp 247-70.

Hildebrand, M. \& Goslow, G. E. Analysis of vertebrate structure. $5^{\text {th }}$ ed. New York, John Wiley and sons Inc., 2001. pp 201-17.

Kingdon, J. East African Mammals. A: Insectivores and Bats. London, Academic press, 1974. V. 2.
Ogunbiyi, O. A. \& Okon, E. E. Studies on the digestive enzymes of the African fruit bat Eidolon Helium. Comp. Biochem. Physiol., 55:359-61, 1976.

Okon, E. E. Fruit bats at ife: Their roosting and food preferences (Ife fruit bat project no. 2). Nigerian field, 39:33-40, 1974.

Redford, K. H. Curious creatures to whom the ant is la haute cuisine. Smithsonian, 14:74, 1983.

Redford, K. H. \& Dorea, J. G. The nutritional value of invertebrates with emphasis on ants and termites as food for mammals. J. Zool., 203:385-95, 1984.

Rouk, C. S. \& Glass, B. P. Comparative gastric histology of five North and Central American bats. J. Mammal., 51:455-72, 1970.

Rubin, W. The epithelial "membrane" of small intestine. Am. J. Clin. Nuts., 24(1):45-64, 1971.

Saladin, K. S. Anatomy and Physiology - The unity of form and function. $3^{\text {rd }} \mathrm{ed}$. Madison, McGraw-Hill, 2004. p 950.

Thomas, D. W. On fruits, seeds, and bats. Bats, 9:8-13, 1991.

Wilson, J. P. Surface area of the small intestine in man. Gut., 8:618-21, 1967.

World Health Organization. Calibrating the microscope. In: Basic laboratory methods in medical parasitology, Geneva, WHO, 1991.

Correspondence to:

Ofusori, D. A

Department of Anatomy

School of Basic Medical Sciences

Igbinedion University, Okada,

P.M.B 0006, Benin City

Edo State

NIGERIA

Tel: +2348034455715

Email: davidofus234@yahoo.com

Received: 04-08-2007

Accepted: 23-09-2007 
